\title{
Indonesian Banking Efficiency in the Post-Asian Monetary Crisis
}

\author{
Budi Santosa \\ \{budi_santosa@trisakti.ac.id\} \\ Faculty of Economics and Business, Universitas Trisakti, Indonesia
}

\begin{abstract}
This study examines the determinants of Indonesian banking efficiency in post-Asian monetary crisis. It used a quantitative approach and historical data, where the data used is both time series (2000-2012), and crosssectional (for some commercial banks that meet the requirements of the sample). Conceptually, it will rely upon the concept of efficiency proposed by Farrell (1957). Meanwhile, banking efficiency measurement techniques are used in the DEA with the intermediation approach as the basis for the selection of input and output. In the application of DEA, it will use both CRS models (models CCR) and VRS (BCC models). While in its construction, it will use an input-oriented approach. From here we identify the variables that affect the Indonesian banking efficiency in the post-Asian monetary crisis, by using Tobit Regression Model. Based on the sample of 17 commercial banks, our findings reveal that the efficiency of Indonesian commercial banks via the intermediation approach has been running normally and tends to be efficient in the post-Asian monetary crisis. In addition, banks in Indonesia are significantly affected by Size, State Ownership, Private Ownership, Non-merger, Foreign Ownership, Risk, and Economic Growth. From the study, it appears that the Size and Ownership of both state-private and domestic-foreign are variables that affect the Overall Technical Efficiency (OTE), Pure Technical Efficiency (PTE), and Scale Efficiency (SE). Furthermore, Non-Merger is a variable that affects the Overall Technical Efficiency (OTE), and Scale Efficiency (SE). Meanwhile, Risk affects only Pure Technical Efficiency (PTE), as well as Economic Growth which only affects Overall Technical Efficiency (OTE). Instead, Competition, Inflation, and Global Crisis did not affect all types of efficiency.
\end{abstract}

Keywords: Efficiency; Banking; Data Envelopment Analysis (DEA); Asian Monetary Crisis

\section{Introduction}

In almost all countries, the banking industry plays a very crucial role in economic development and welfare. At the global level, banking institutions also face the challenges of globalization and international competition. Competition not only among domestic banks but also between domestic banks with foreign banks. In that context, the presence of sound and efficient banking institutions is inevitable.

In Indonesia, the role of the banking industry is more dominant and strategic, so attention to the banking efficiency should also be very high, moreover the post-Asian monetary crisis 1997 cause turmoil in the banking industry. This study aims to analyze the factors that affect 
Indonesia's banking efficiency in the post-Asian monetary crisis. Accordingly, two main issues are closely related to the study are: how are the levels of Indonesian banking efficiency in the post-Asian monetary crisis? And what variables significantly influence the Indonesian banking efficiency in the period?

\section{Framework and Empirical Studies}

Banking efficiency describes the ability of the bank concerned in managing its input and output. In the perfect competition structures that approach the perfectly competitive market, the banks are less efficient can be eliminated from the market because it is not able to compete with its competitors, both in terms of pricing and in terms of product quality and service. The concept of efficiency can be traced in the microeconomic theory, both in the theory of consumption and production theory. In the theory of consumption, the concept was known as maximizing utility or satisfaction. While in production theory, the concept was known as maximize profits or minimize costs [1].

According to [2], efficiency comprises of two components, namely: technical efficiency and allocative efficiency. This concept measures the ratio of the input level to the output level. Technical efficiency can be breakdown into Pure Technical Efficiency (PTE) and Scale Efficiency (SE). The PTE measure is obtained by estimating the efficient frontier under the assumption of variable returns to scale (VRS). It is a measure of technical efficiency without scale efficiency and purely reflects managerial performance in organizing the inputs into the production process. Thus, the PTE measure has been used as an index to capture managerial performance. The measure of SE demonstrates the ability of the management to choose the optimum size of resources, i.e. to decide on the firm's size or in other words, to choose the scale of production that will attain the expected production level. The inappropriate size of a firm (too large or too small) may sometimes be a cause of technical inefficiency [3]. This measurement related to the scale of the firm is usually described by the size of its assets.

Non-parametric approaches measure efficiency using the non-stochastic approach that tends to combine disturbance into inefficiency. The most important method of this approach is known as Data Envelopment Analysis (DEA). DEA is a mathematical programming approach to build an efficient frontier and measure the relative efficiency of each decision-making unit (DMU) are investigated for the efficient frontier constructed. DEA measures the efficiency of a decision-making unit (DMU) relative to other similar DMUs with the simple restrictions that all DMUs lay on or below the efficiency frontier. DEA can also determine how a DMU can improve its performance to become efficient [4]. Further, a DEA model can be constructed either to minimize inputs or to maximize outputs. An input orientation aims at reducing the input amounts as much as possible while keeping at least the present output levels, while an output orientation aims at maximizing output levels without increasing the use of inputs [5], [6].

Mishkin (2007) said that banks are financial institutions that accept money deposits and make the loan. In other words, the scope of certain banking activities is as an intermediary institution that turns money borrowed from depositors (surplus spending unit) into money lent to borrowers (deficit spending units) [7], [4], [5], [8]. Size is one of the elements of market structure that is much discussed concerning its effect on banking efficiency. The researchers believed that there is a relationship between size and efficiency. However, the conclusion on the pattern of relationship between them both is contrary between the market power (MP) hypothesis and the efficient structure (ES) hypothesis. According to the market power (MP) 
hypothesis, highly concentrated banking industries are likely to perform poorly. Because they allocate resources inefficiently, employing too few factors of production and channeling too many into less concentrated industries [6], [9]. Otherwise, the efficient structure (ES) hypothesis suggests that the efficient operation of banks determines market structure. Efficient banks increase size and bank's market share because of their ability to generate higher profit, which usually leads to higher market concentration. In this hypothesis larger market share of banks simply represents the degree of banking efficiency [10], [11], [12], [13], [14], [15].

The level of market concentration also indicates the condition of banking competition in a market. Some experts believed that the condition of competition in the market is a very significant influence on the efficiency of the banking system. Theoretically, a competitive banking industry, as indicated by the low level of concentration of the banking industry, will create a bank with a high level of efficiency. The degree of competition in the banking sector affects efficiency in the provision of banking services, their quality, and innovation. General economic theory suggests that increased competition results in lower profits and thus enhanced efficiency in the domestic banking system [16], [17]. However, on the other hand, the truth of the postulate is contradicted by two other empirical studies [18], [19].

Mergers are often motivated by a desire to increase economic efficiency, and some mergers result in significant efficiency gains. Economic of scale may result from any merger but are most common in horizontal mergers. A horizontal merger may enable the consolidated firm to reduce its production or marketing costs [20]. Moreover, according to Berger [21], profit efficiency is enhanced by mergers because the combined firms generally achieve greater diversification of their risk exposures through a better mix of geographic areas, industries, loan types, and maturity structures. In turn, improved diversification might allow the combined banking organization to undertake a portfolio shift from security investments into consumer and business loans - activities with higher expected values. Hence, profit efficiency would be greater with consolidation because capital is put to better use and because greater geographic diversification tends to reduce risk. Berger's postulate is supported by several empirical studies [22], [23], [24]. However, the study of Liang [25] rejected these postulates.

Banking firms have heterogeneous characteristics of ownership. In that context, Leibenstein [26] considers that there is a relationship explicitly agent and principal, as a source of inefficiency. These relationships often result in an imperfect contract, giving rise to excessive costs due to information asymmetry. In this case, the managers act under their interests, rather than adhere to the interests of the principal. Based on these arguments, it is interesting to analyze the influence of characteristics of ownership on efficiency. Therefore, comparing the effect of bank ownership on efficiency comparisons can be divided into two comparisons, namely between state and private-owned banks; and between domestic and foreign-owned banks. Several studies comparing the efficiency between state and private banks suggested that the findings are not conclusive. A study by Figueira et al [27] found that privately-owned banks outperform state-owned banks, but the study of Altunbas et al [28] found the opposite conclusion.

The relationship between banking efficiency and ownership may exist due to spillover effects from the superior performance of foreign-owned banks compared with domesticowned banks, which are always considered to be lagging in terms of managerial skills, technologies, and networks. Those performances such as the introduction of new, more diverse products, greater use of up-to-date technologies, and know-how spillovers (e.g., as people learn new skills from foreign banks, they migrate over time to domestic banks) [29]. Thus, foreign-owned banks are often considered to be more efficient than domestic-owned 
banks. Such a view is supported by several empirical studies [30], [12], [31]. However, empirically foreign banks are not always more efficient than domestic-owned banks [32], [5].

One aspect of the performance that also influences the efficiency of banking is a risk. Changes in bank risk influence their efficiency levels. For instance, increases in bank risk may temporally precede a decline in cost efficiency related to lower credit screening [33]. So there is a negative relationship between risk and banking efficiency [34], [10]. However, two studies are contrary to the findings [35], [31].

Banking efficiency is also influenced by the macroeconomic conditions of a country where the banks operate. The relationship between economic growth and efficiency is negative [34]. That seemingly unexpected result is not in line with the findings outlined by Sufian et al [10], who found a positive relationship between economic growth and efficiency based on a sample of Malaysian banks. Also, the results indicate a positive and significant relationship at the $10 \%$ level between inflation and productive efficiency. The global crisis occurred in the period 2008 to 2010 . Some experts examine the influence of the global crisis on banking efficiency and concluded that there is a negative relationship between crisis and banking efficiency [32], [36].

\section{Methodology}

Based on the intermediation approach, this study specifies two inputs and two outputs. The inputs are fixed assets and total deposits. While, the outputs are total loans and liquid assets [17], [37], [38], [19], [39], [40]. Input-oriented measures mean that when a certain amount of input can be reduced proportionally to produce the same level of output. DEA model for a DMU is in a linear fractional program, with the inputs and outputs of DMUs as decision variables. Here is the general form of the CCR DEA Models with the input-oriented approach that will be applied in this study [41].

$$
M \ln z^{t}=\sum_{t=1}^{I} U_{t m}^{t} X_{t m}^{t}
$$

Subject to

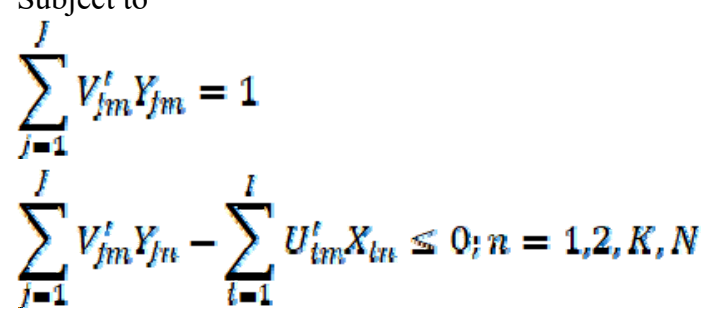

$$
V_{f m}^{f}, U_{t m}^{t} \text { 르, } t=1,2, K_{,}, I, f=1,2, K_{3} J
$$

While the general form of VRS DEA Models with the input-oriented approach that will be applied in this study are as follows. 
$M i n z^{t}=\sum_{t=1}^{I} U_{t m}^{t} X_{t m}$

Subject to

$\sum_{j=1}^{I} V_{l m}^{t} Y_{j m}=1$

$\sum_{j=1}^{I} V_{m}^{t} Y_{l n}-\sum_{i=1}^{I} U_{m}^{t} X_{m n}, 0 ; n=1,2, K, N$

N

$\sum_{n=1} \lambda_{n}=1$

$V_{t m}^{t}, U_{t m}^{t}$ m

Where:

$z^{\prime}$ is the efficiency of the $m$ th DMU,

$U_{t m}^{t}$ is the weight of that input,

$X_{t m}$ is $i$ th input of the $m$ th DMU,

$V_{t m}^{\prime}$ is the weight of that output,

$Y_{m m}$ is $a j$ th output of the $m$ th DMU, and

$Y_{m}$ and $X_{t n}$ are $j$ th output and $i$ th input, respectively, of the $n$th DMU, $n=1,2, \ldots, \mathrm{N}$.

$\sum_{n=1}^{\mathbb{V}} \lambda_{n}=1$ is the convexity constraint

$\epsilon$ is a non-Archimedean number.

Note that here $n$ includes $m$.

So the next step is that the efficiency scores obtained are associated with those factors that influence it. This step is performed by using regression analysis to explain the variation that occurs between the values of efficiency. However, the problem is not all the regression models can be used for it. Ordinary Least Square (OLS) regression is considered less suitable because the values of efficiency as the dependent variable, are limited in the censored data on a scale of $0-1$. Therefore, we need other appropriate regression models. In connection with that, Casu and Molyneux (2003) [42] proposed the use of the Tobit Regression model for that purpose, because the model is considered more suitable for censored or truncated data. Some researchers have also applied the model to their study including Ali and Afzal (2011) [6], Sufian and Noor (2009) [10], Hahn (2007) [43], and Worthington (2001) [22]. Based on those studies, we will employ the model for this study. The variables are shown in the formula below:

$Y_{i}=b_{1}$ SIZE $+b_{2}$ COMPETITION $+b_{3}$ NONMERG_MERG $+b_{4}$ OWNERSHIP $+b_{5}$ RIS
$+b_{6}$ ECONOMICGROWTH $+b_{7}$ INFLATION $+b_{8}$ GOBALCRISIS $+e_{i}$

Where: 


$\begin{array}{lll}Y_{t} & : & \text { Efficiency scores } \\ \text { SIZE } & : & \text { Total asset } \\ \text { COMPETITION } & : \text { Herfindahl-Hirschman Index (HHI) } \\ \text { NONMERG_MERG } & : \text { Non-merger/Merger, 0 if the bank is Non-merger; } 1 \text { if Merger } \\ \text { OWNERSHIP } & : \text { State/Private, 0 if the bank is State; 1 if Private } \\ & : \text { Domsetic/Foreign, 0 if the bank is Domestic; } 1 \text { if Foreign } \\ \text { RISK } & : \text { Non-Performing Loan (NPL) } \\ \text { ECONOMICGROWTH } & : \text { Growth rate } \\ \text { INELATION } & : \text { Inflation rate } \\ \text { GLOBALCRISIS } & : \text { 0 If period in 2000-2007 and 2011-2012, } 1 \text { if 2008-2010 } \\ b_{1}-b_{8} & : & \end{array}$

This study proposes the major hypotheses: The explanatory variables namely size, competition, non-merger and merger, ownership, risk, economic growth, inflation, and global crisis that significantly influence the banking efficiency in Indonesia, in the post-Asian monetary crisis.

This study will be focused on commercial banks only, by excluding Sharia Commercial Bank (Bank Umum Syariah)/BUS), Sharia Business Unit (Unit Usaha/Syariah/UUS), Regional Development Bank (BPD), and Joint Venture Banks (Bank Campuran). So, the population used all commercial banks operating in Indonesia, which has existed since before 1990 and still operated from 2000 to 2012. The selection of samples was conducted by nonprobability or not random, elements of the population do not have the same opportunity to being selected as the sample. The technique used to obtain a representative sample is purposive sampling. The technique is non-random sample selection in which the information is obtained by using a certain consideration, which is generally adapted to the purpose or problem.

\section{Discussion on Empirical Results}

The first analysis is testing the goodness of fit of the model. The test of goodness of fit model uses the LR $\mathrm{Chi}^{2}$ value. The model used already fits with the empirical data if the probability value is smaller than the critical value. The result of the test is shown in Table 1 in the following.

Table 1. The goodness of Fit Test of Indonesian Banking Efficiency

\begin{tabular}{ccc}
\hline Efficiency & LR $\mathbf{C h i} \mathbf{~}^{\mathbf{2}}$ & Prob $(\mathbf{0 . 0 1})>\mathbf{C h i}^{\mathbf{2}}$ \\
\hline OTE & 225.49 & 0.0000 \\
PTE & 95.42 & 0.0000 \\
SE & 152.37 & 0.0000 \\
\hline
\end{tabular}

Source: Results from STATA Software version 12 .

The analysis shows that the LR $\mathrm{Chi}^{2}$ value for each model (Overall Technical Efficiency (OTE), Pure Technical Efficiency (PTE), and Scale Efficiency (SE) are respectively 225.49, 95.42, and 152.37. The probability values of OTE, PTE, and SE are 0.0000, smaller than the significance level of 0.01 . So, the model used matches the empirical data and can be used for further analysis. It also can be interpreted as the F test, similarly in the analysis of ordinary least square (OLS). Thus, it can be interpreted that: size, competition, merger, ownership, risk, 
economic growth, inflation, and the global crisis, together significantly affect on each of the three types of efficiency.

Furthermore, the regression results are shown in Table 2 below.

Table 2. Summary of Significant Variable Affecting on Indonesian Banking Efficiency

\begin{tabular}{|c|c|c|c|c|c|c|}
\hline Efficiency & Variable & Coefficient & Standard Error & t-Statistic & P-Value & Remark \\
\hline \multirow[t]{5}{*}{ OTE } & Log size & 1.762949 & 0.453077 & 3.89 & $0.000 * * *$ & $\begin{array}{l}\text { Reject } \\
\text { H013/Accept } \\
\text { Ha13 }\end{array}$ \\
\hline & Merg & -4.372592 & 2.239019 & -1.95 & $0.052 *$ & $\begin{array}{l}\text { Reject H015/ } \\
\text { Accept Ha15 }\end{array}$ \\
\hline & Ownsp & 5.435647 & 3.029218 & 1.79 & $0.074 *$ & $\begin{array}{l}\text { Reject } \\
\text { H016/Accept } \\
\text { Ha16 }\end{array}$ \\
\hline & Owndf & 31.92526 & 1.796969 & 17.77 & $0.000 * * *$ & $\begin{array}{l}\text { Reject } \\
\text { H017/Accept } \\
\text { Ha117 }\end{array}$ \\
\hline & Ecgr & 2.190575 & 1.070155 & 2.05 & $0.042 * *$ & $\begin{array}{l}\text { Reject } \\
\text { H019/Accept } \\
\text { Ha19 }\end{array}$ \\
\hline \multirow[t]{4}{*}{ PTE } & Logsize & 4.602862 & 0.7689323 & 5.99 & $0.000 * * *$ & $\begin{array}{l}\text { Reject } \\
\text { H013/Accept } \\
\text { Ha13 }\end{array}$ \\
\hline & Ownsp & -13.71328 & 5.136826 & -2.67 & $0.008 * * *$ & $\begin{array}{l}\text { Reject } \\
\text { H016/Accept } \\
\text { Ha16 }\end{array}$ \\
\hline & Owndf & 18.83744 & 3.051409 & 6.17 & $0.000 * * *$ & $\begin{array}{l}\text { Reject } \\
\text { H017/Accept } \\
\text { Ha117 }\end{array}$ \\
\hline & Risknpl & 0.3007642 & 0.1601956 & 1.88 & $0.062 *$ & $\begin{array}{l}\text { Reject } \\
\text { H018/Accept } \\
\text { Ha118 }\end{array}$ \\
\hline \multirow[t]{4}{*}{ SE } & Logsize & -1.62266 & 0.7412642 & -2.19 & $0.030 * *$ & $\begin{array}{l}\text { Reject H013/ } \\
\text { Accept Ha13 }\end{array}$ \\
\hline & Merg & -6.757794 & 3.676497 & -1.84 & $0.067 *$ & $\begin{array}{l}\text { Reject H015/ } \\
\text { Accept Ha15 }\end{array}$ \\
\hline & Ownsp & 24.06257 & 4.958256 & 4.85 & $0.000 * * *$ & $\begin{array}{l}\text { Reject } \\
\text { H016/Accept } \\
\text { Ha16 }\end{array}$ \\
\hline & Owndf & 29.1517 & 2.948696 & 9.89 & $0.000 * * *$ & $\begin{array}{l}\text { Reject } \\
\text { H017/Accept } \\
\text { Ha117 }\end{array}$ \\
\hline
\end{tabular}

Source: Summary from STATA Software version 12 results.

*** Indicates $1 \%$ level of significance.

** Indicates $5 \%$ level of significance.

* Indicates $10 \%$ level of significance.

From Table 2 it appears that the Size and Ownership of both state-private and domesticforeign are variables that affect the OTE, PTE, and SE. Furthermore, Merger is a variable that affects the OTE, and SE. Meanwhile, Risk affects only PTE, as well as Economic Growth 
which only affects OTE. Instead, Competition, Inflation, and Global Crisis did not affect all types of efficiency.

In the case of OTE and PTE, Size has a positive relationship with banking efficiency. The findings prove the truth of the efficient structure (ES) hypothesis that suggests that the efficient operation of banks determines market structure. Meanwhile, the effect of Size on SE is negative which means the greater Size of banks, the lower the efficiency. The finding proves the truth of the Market Power (MP) hypothesis that highly concentrated banking industries are likely to perform poorly. Because they allocate resources inefficiently, employing too few factors of production and channeling too many into less concentrated industries (Caves, 1967).

Furthermore, this study finds that Non-merger is more efficient than Merger on OTE and SE. This finding is inconsistent with the several previous findings that in general, merger banks are more efficient than non-merger banks. This finding raises a serious question that although the performance of merger banks appears more efficient than non-merger banks, their role in the creation of the overall banking efficiency is still questionable.

Meanwhile, State-Private Ownership is also a variable that affects the level of banking efficiency. However, the effect shows that the pattern is not uniform in Indonesia, where Private Ownership is more efficient than State Ownership in terms OTE and SE. Meanwhile, in terms of PTE, State Ownership is more efficient than Private Ownership. As might be expected, Foreign Ownership has more efficient on three types of efficiency, compared to Domestic Ownership. This finding is consistent with the previous findings where in general, foreign banks are more efficient than domestic banks.

Risk influences positively to PTE. This finding strengthens the finding of Fathony (2012) [44] who found that the bank that issued the greater cost in doing the guarantee and supervision of the loan portfolio is relatively in the short term to be inefficient, but in the long run, be more efficient through a low-cost bad credit. While Economic Growth has a positive influence on the OTE. The finding vindicated the postulate of Sufian and Habibullah (2010) [45] who stated that generally higher economic growth encourages banks to lend more and permits them to charge higher margins, as well as improving the quality of their assets. As gross domestic product (GDP) growth slows down and in particular during recessions, credit quality tends to deteriorate and default rates increase, thus reducing bank efficiency (Sufian and Habibullah, 2012) [45]. In addition, this finding also confirms the study of Rangkakulnuwat and Wang (2007) [46] who found that increases in the growth rate of GDP also improve banks' efficiency.

\section{Conclusion}

Banking efficiency in Indonesia is significantly affected by Size, State Ownership, Private Ownership, Non-merger, Foreign Ownership, Risk, and Economic Growth. To improve PTE, Indonesian banking should improve the managerial performance of the bank's managers in organizing the inputs into the intermediation process. This policy can be realized through training for them to improve their skills in the application of efficient cost management in the banks that they lead. Domestic banks in Indonesia should take advantage of the presence of foreign banks in the country. They have to catch up to foreign banks in terms of technology, best-practice standards, and IT development (i.e. internet banking, e-money), to improve their efficiency.

Indonesian banking should apply the knowledge, capability of management, managerial incentives, good corporate governance, and efficient cost management in its operations, to be 
saving for transforming fixed assets and total deposits into total loans and liquid assets. It should strengthen its capital structure, to carry out its operations in the economics of scale. For that, they can be merged to improve their efficiency to be able to compete with the big and foreign banks. The merger will lead to market power will increase and have high competitiveness with other banks which resulted in lower operating costs and increase efficiency levels. The advantages of the merger in the long term are expected to be realized.

Indonesian banking should improve further restructuring and privatization programs, especially for banks that have not been efficient, so it will be more competitive. The policy can be done by increasing the capital, enhancing technical skills, managerial, operational, and skills, especially for human resources. Bank restructuring should be continued with more intensive treatment because the bank restructuring will affect the economic recovery. In addition, regulators should encourage the Net Interest Margin (NIM) will be lower, efficient, and conducive to the real sector. To improve the banking efficiency, the Indonesian authorities should implement financial reform package that creates healthy competition in the banking industry, and also provide an incentive scheme to improve managerial efficiency.

\section{References}

[1] Case, K.E., Fair, R.C. and Oster, S.M.: Principles of economics. 10th Edition. Prentice Hall, US (2012)

[2] Farell, M.J.: The measurement of productive efficiency. The Journal of Developing Areas. Vol. 120, no. 3, pp. 253-290 (1957)

[3] Kaur, K. and Kumar, S.: Corporate ownership and the technical and scale efficiency of pharmaceutical firms in India - empirical evidence. South East European Journal of Economics and Business. Vol. 5, no. 2, pp. 95-106 (2010)

[4] Ascarya and Yumanita, D.: Comparing the efficiency of Islamic banks in Malaysia and Indonesia. Buletin Ekonomi dan Perbankan. Vol. 11, no. 2 (2009)

[5] Sufian, F.: The efficiency of Islamic banking industry in Malaysia: Foreign vs domestic banks. Humanomics. Vol. 23, no. 3, pp. 174-192 (2007)

[6] Ali, R. and Afzal, M.: Post financial deregulations era and efficiency of Pakistan banking sector. Interdisciplinary Journal of Contemporary Research in Business. Vol. 3, no. 8, pp. 1177-1187 (2011)

[7] Mishkin, F.S.: The economics of money, banking, and financial markets. Eight Edition. Pearson Addison Wesley, US (2007)

[8] Yudistira D.: Efficiency in Islamic banking: an empirical analysis of eighteen banks. Islamic Economic Studies. Vol. 12-1, no. 1, pp. 2-19 (2004)

[9] Papadopoulos, S. and Karagiannis, S.: Recent evidence on efficiency in Southern European banking. Studies in Economics and Finance. Vol. 26, no. 2, pp. 95-112 (2009)

[10] Sufian, F. and Noor, M.A.N.M.: The determinants of Islamic banks' efficiency changes: Empirical evidence from the MENA and Asian banking sectors. International Journal of Islamic and Middle Eastern Finance and Management. Vol. 2, no. 2, pp. 120-138 (2009)

[11] Delis, M.D. and Papanikolaou, N.I.: Determinants of bank efficiency: Evidence from a semi-parametric methodology. Managerial Finance. Vol. 35, no. 3, pp. 260-275 (2009)

[12] Nikiel, E.M. and Opiela, T.P.: Customer type and bank efficiency in Poland: Implications for emerging market banking. Contemporary Economic Policy. Vol. 20, 
no. 3, pp. 255-271 (2002)

[13] Kumar, S. and Gulati, R.: Evaluation of technical efficiency and ranking of public sector banks in India: An analysis from cross-sectional perspective. International Journal of Productivity and Performance Management. Vol. 57, no. 7, pp. 540-568 (2008)

[14] Molyneux, P.: Increasing concentration and competition in European banking: The end of anti-trust ?. Erasmus. Vol. 4, no. 1, pp. 127-136 (1999)

[15] Weill, L.: Measuring cost efficiency in European banking: A comparison of frontier techniques. Journal of Productivity Analysis. Vol. 21, no. 2, pp. 133-152. (2004)

[16] Herberholz, C., Sawangngoenyuang, W. and Subhanij,T.: The Impact of the changing financial landscape on Thai banks. The Sixth National Conference of Economists Conference Proceeding. pp. 1-35 (2010)

[17] Suzuki, Y. and Sastrosuwito, S.: Efficiency and productivity change of the Indonesian commercial banks. International Conference on Economics, Trade and Development IPEDR. IACSIT Press. Vol. 7, pp. 10-14 (2011)

[18] Mlambo, K. and Ncube, M.: Competition and efficiency in the banking sector in South Africa. African Development Review. Vol. 23, no. 1, pp. 4-15 (2011)

[19] Weill, L.: Banking efficiency in transition economies. The Economics of Transition. Vol. 11, no. 3, pp. 569-592 (2003)

[20] Lelissa, T. B.: The structure conduct performance model and competing hypothesis- a review of literature the structure conduct performance model and competing. Research Journal of Finance and Accounting. Vol. 9, no. 1, pp. 76-89 (2018)

[21] Berger, A.N.: The efficiency effects of bank mergers and acquisition: A preliminary look at the 1990s data. Bank Mergers and Acquisitions. pp. 79-111 (1998)

[22] Worthington, A.C.: Efficiency in pre-merger and post-merger non-bank financial institutions. Managerial and Decision Economics. Vol. 22, no. 8, pp. 439-452 (2001)

[23] Punt, L.W. and Van Rooij, M.C.J.: The profit-structure relationship and mergers in the European banking industry: an empirical assessment. Netherlands Central Bank, Research Department. Staff Reports. pp. 58 (2001)

[24] Al-Sharkas, A.: Short-term, long-term, and efficiency impacts of recent mergers and acquisitions in the U.S. banking industry. Working Paper. University of New Orleans. pp 163 (2004)

[25] Liang, L.W.: The impact of bank mergers on the cost efficiency of Taiwanese and Japanese banking. Journal of Accounting, Finance \& Management Strategy. Vol. 6, no. 1, pp. 59-82 (2011)

[26] Leibenstein, H.: Allocative efficiency vs. X-efficiency. Die 100 wichtigsten Werke der Ökonomie. pp. 124-125 (2019)

[27] Figueira, C.,Nellis, J., Parker, D.: Does ownership affect the efficiency of African banks?. The Journal of Developing Areass. Vol. 40, no. 1, pp. 37-62 (2006)

[28] Altunbas, Y., Evans, L., \& Molyneux, P.: Bank ownership and efficiency. Journal of Money, Credit, and Banking. Vol. 33, no. 4, pp. 926 (2001)

[29] Claessens, S and Van Horen, N.: Foreign banks: Trends, impact and financial stability. IMF Working Paper. Vol. 10, pp. 1-36 (2012)

[30] Grigorian, D.A. and Manole, V.: Determinants of commercial bank performance in transition: An application of data envelopment analysis. Comparative Economic Studies. Vol. 48, no. 3, pp. 497-522 (2006)

[31] Barry, T. A., Dacanay, S.J.O., Lepetit, L. and Tarazia, A.: Ownership structure and bank efficiency in six Asian countries. Philippine Management Review (Special Issue). 
Vol. 18, no. 2003, pp. 19-35 (2010)

[32] Anayiotos, G., Toroyan, H., and Vamvakidis, A.: The efficiency of emerging Europe's banking sector before and after the recent economic crisis. Financial Theory and Practice. Vol. 34, no. 3, pp. 247-267 (2010)

[33] Fiordelisi, F., Marques-Ibanez, D. and Molyneux, P.: Efficiency and risk in European banking. Journal of Banking \& Finance, Elsevier. Vol. 35, no. 5, pp. 1315-1326 (2010)

[34] El Moussawi, C. and Obeid, H.: Evaluating the productive efficiency of Islamic banking in GCC: A non parametric approach. International Management Review. Vol. 7, no. 1, pp. 178-190 (2010)

[35] Seelanatha, S.L.: Efficiency, productivity change and market structure of the banking industry in Sri Lanka.Working Paper. University of Southern Queensland (2007)

[36] Maredza, A., and Ikhide, S.: Measuring the impact of the global financial crisis on efficiency and productivity of the banking system in south Africa. Mediterranean Journal of Social Sciences. Vol. 4, no. 6, pp. 553-568 (2013)

[37] Bos, J.W.B. and Kool, C.J.M.: Bank efficiency: The role of bank strategy and local market conditions. Journal of Banking and Finance. Vol. 30, no. 7, pp. 1953-1974 (2006)

[38] Holló, D. and Nagy, M.: Bank efficiency in the enlarged European Union. MNB Working Papers, No. 2006/3, Magyar Nemzeti Bank, Budapest (2006)

[39] Berger, A.N. and Humphrey, D.B.: Efficiency of financial institutions: International survey and directions for future research. European Journal of Operational Research. Vol. 98, pp.175-212 (1997)

[40] Berger, A.N. and Mester, L.J.: Inside the black box: What explains differences in the efficiencies of financial institutions?. Journal of Banking and Finance. Vol. 21, no. 7, pp. 895-947 (1997)

[41] Cooper, W.W., Seiford, L.M., and Zhu, J.: Data envelopment analysis history, models and interpretations. Handbook on Data Envelopment Analysis. pp. 1-39 (2011)

[42] Casu, B. and Molyneux, P.: A comparative study of efficiency in European banking. Working Paper. School of Accounting, Banking and Economics. Vol. 35, no. 17, pp. 1865-1876. University of Wales, Bangor (2003)

[43] Hahn F. R.: Environmental determinants of banking efficiency in Austria. Empirica. Vol. 34, no. 3, pp. 231-245 (2007)

[44] Moch. Fathony, Estimasi dan Faktor-faktor yang Mempengruhi Efisiensi Bank Domestik dan Asing di Indonesia, Jurnal Keuangan dan Perbankan. Vol. 16, no. 2, pp. 223-237, 2012

[45] Sufian F. and Habibullah, M. S.: Developments in the efficiency of the Thailand banking sector: a DEA approach. International Journal Development Issues. Vol. 9, no. 3, pp. 226-245 (2010)

[46] P. Rangkakulnuwat and H. H. Wang, Technical efficiency of thai commercial banks: the output distance function approach, Thailandnce.Eco.Ku.Ac.Th, August, (1997) 